\title{
Lymphocyte glucocorticoid receptor binding during depression and after clinical recovery
}

\author{
Rainer Rupprecht ${ }^{1,2}$, Johannes Kornhuber ${ }^{1}$, Norbert Wodarz ${ }^{1}$, Johannes Lugauer ${ }^{1}$, \\ Claudia Göbel ${ }^{\text {, }}$ Peter Riederer ${ }^{1}$ and Helmut Beckmann ${ }^{1}$ \\ ${ }^{\prime}$ Department of Psychiatry, University of Würzburg and ${ }^{2}$ Max-Planck-Institute for Psychiatry, Munich, F.R.G.
}

(Received 16 November 1990)

(Revision received 31 January 1991)

(Accepted 4 February 1991)

\begin{abstract}
Summary
Lymphocyte glucocorticoid receptor binding parameters were studied in 15 severely depressed patients during depression and after clinical recovery, and in 15 healthy controls. There was no difference in glucocorticoid receptor number or affinity between depressed patients and recovered or control subjects. Afternoon ACTH and cortisol concentrations did not differ significantly between the three groups. No relationship could be established between glucocorticoid receptor binding and antidepressant medication. These data support the view of an impaired ligand-induced plasticity of glucocorticoid receptor regulation rather than the hypothesis of decreased glucocorticoid receptor numbers during depression.
\end{abstract}

Key words: Glucocorticoid receptors; Binding; Depression; Antidepressants

\section{Introduction}

Abnormalities of hypothalamic-pituitary-adrenal (HPA) system integrity linked to depression include 24-h hypersecretion of cortisol during depressive episodes (Linkowski et al., 1985, 1987), and reduced suppression of cortisol by dexamethasone (Carroll et al., 1968). An escape of plasma adrenocorticotropic hormone (ACTH)

Address for correspondence: Dr. R. Rupprecht, MaxPlanck-Institute for Psychiatry, Kraepelinstr. 10, 8000 München 40, F.R.G.
(Fang et al., 1981) and $\beta$-endorphin (Matthews et al., 1986; Rupprecht et al., 1988) from dexamethasone suppression in endogenously depressed patients provided further evidence for a subtle derangement of the feedback regulation of the HPA system during depression. Moreover, reports of an inadequate suppressibility of prolactin (Meltzer et al., 1982; Rupprecht et al., 1987) and thyroidstimulating hormone (TSH) (Rupprecht et al., 1989) following glucocorticoid administration in depression have supported the idea that the derangement of the glucocorticoid-mediated negative feedback is not restricted to the HPA system, but also involves a variety of neuroendocrine sys- 
tems. These neuroendocrine abnormalities seem to be state-dependent since the hypercortisolemia (Linkowski et al., 1987) and the disturbed response to dexamethasone (Rupprecht et al., 1989) revert to normal values after clinical recovery.

Several authors have investigated lymphocyte glucocorticoid receptors (GR) in depression. The results of these studies differed quite considerably. Some reports noted lower GR sites per cell in depressed patients (Gormley et al., 1985; Whalley et al., 1986), while others found a reduced downregulation of GR concentrations only in dexamethasone suppression test (DST) non-suppressors (Lowy et al., 1988) or could not detect differences between depressed patients and controls or between DST non-suppressors and suppressors (Schlechte and Sherman, 1985). In addition, normal GR values have been reported in patients after recovery from major depressicn when compared with healthy controls (Hunter et al., 1988).

As no data are available on GR binding parameters during depression and after recovery in the same subjects, a follow-up study was undertaken to study GR with regard to antidepressant treatment.

\section{Subjects and methods}

Subjects

Five male and 10 female subjects with unipolar major depressive disorder or bipolar depression aged between 18 and 66 years (mean \pm SD $48.2 \pm$ 14.8 years) with a mean $( \pm S D)$ body weight of $72.5 \pm 13.3 \mathrm{~kg}$ and three male and 12 female healthy controls aged between 33 and 57 years (mean $\pm \mathrm{SD} 47.3 \pm 7.4$ years) with a mean $( \pm \mathrm{SD})$ body weight of $68.4 \pm 10.2 \mathrm{~kg}$ were studied. All subjects were carefully screened for medical illness that might influence pituitary-adrenal function by medical history, physical examination and routine laboratory tests. Six female depressed patients and five female controls were tested during the midluteal phase of the cycle; the other females were postmenopausal.

DSM-IIIR (American Psychiatric Association, 1987) diagnoses were made on all patients by the

TABLE 1

DEMOGRAPHIC DATA. ANTIDEPRESSANTS PRIOR TO THE WASHOUT PERIOD AND DIAGNOSTIC DESCRIPTION OF THE DEPRESSED PATIENTS

\begin{tabular}{|c|c|c|c|c|c|c|}
\hline Patient & $\begin{array}{l}\text { Age } \\
\text { (years)/sex }\end{array}$ & DSM-IIIR & $\begin{array}{l}\text { 21-HRSD } \\
\text { depressed }\end{array}$ & $\begin{array}{l}\text { Drug-free period } \\
\text { (days) }\end{array}$ & $\begin{array}{l}\text { Treatment before } \\
\text { drug-free period }\end{array}$ & $\begin{array}{l}\text { Depressive } \\
\text { episodes }\end{array}$ \\
\hline$i$ & $44 / \mathrm{F}$ & bipolar disorder, depressed & 33 & $>28$ & & 3 \\
\hline 2 & $66 / F$ & MDD, recurrent, with melancholia & 36 & $>28$ & & 2 \\
\hline 3 & $61 / \mathrm{F}$ & $\begin{array}{l}\text { MDD, recurrent, with melancholia, } \\
\text { mood-congruent psychotic }\end{array}$ & 28 & $>28$ & & 3 \\
\hline 4 & $64 / \mathrm{F}$ & MDD, recurrent, with melancholia & 28 & $>28$ & & 4 \\
\hline 5 & $39 / \mathrm{F}$ & MDD, recurrent & 25 & 7 & amitryptiline $100 \mathrm{mg}$ & 3 \\
\hline 6 & $60 / \mathrm{M}$ & MDD, recurrent, with melancholia & 24 & 5 & amitryptiline $100 \mathrm{mg}$ & 3 \\
\hline 7 & $60 / \mathrm{M}$ & MDD, recurrent, with melancholia & 28 & 5 & maprotiline $150 \mathrm{mg}$ & 3 \\
\hline 8 & $34 / F$ & MDD, recurrent, with melancholia & 28 & 4 & maprotiline $100 \mathrm{mg}$ & 3 \\
\hline 9 & $49 / \mathrm{M}$ & MDD, single episode & 21 & 7 & maprotiline $100 \mathrm{mg}$ & 1 \\
\hline 10 & $54 / \mathrm{F}$ & bipolar disorder. depressed & 33 & $>28$ & & 6 \\
\hline 11 & $55 / \mathrm{F}$ & MDD, recurrent, with melancholia & 26 & 5 & maprotiline $150 \mathrm{mg}$ & 2 \\
\hline 12 & $26 / \mathrm{F}$ & $\begin{array}{l}\text { MDD, single episode with } \\
\text { melancholia }\end{array}$ & 26 & 4 & amitryptiline $75 \mathrm{mg}$ & 1 \\
\hline 13 & $60 / \mathrm{M}$ & bipolar disorder. depressed & 30 & 4 & clomipramine $150 \mathrm{mg}$ & 6 \\
\hline 14 & $18 / \mathrm{F}$ & MDD, single episode & 26 & $>28$ & & 1 \\
\hline 15 & $53 / \mathrm{M}$ & MDD, recurrent & 26 & $>21$ & & 2 \\
\hline
\end{tabular}

MDD, major depressive disorder. 
TABLE 2

MEDICATION AND CLINICAL DATA OF THE RECOVERED PATIENTS

\begin{tabular}{rrlrc}
\hline Patient & $\begin{array}{l}\text { 21-HRSD } \\
\text { recovered }\end{array}$ & $\begin{array}{l}\text { Treatment after } \\
\text { recovery }\end{array}$ & $\begin{array}{l}\text { Treatment } \\
\text { (days) }\end{array}$ \\
\hline 1 & 10 & amitryptiline & $100 \mathrm{mg}$ & 75 \\
2 & 10 & nortryptiline & $480 \mathrm{mg}$ & 28 \\
3 & 9 & clomipraminc & $100 \mathrm{mg}$ & 24 \\
4 & 1 & lithium & $600 \mathrm{mg}$ & 125 \\
5 & 2 & amitryptiline & $200 \mathrm{mg}$ & 30 \\
6 & 1 & amitryptiline & $150 \mathrm{mg}$ & 30 \\
7 & 9 & amitryptiline & $175 \mathrm{mg}$ & 90 \\
8 & 10 & clomipramine & $75 \mathrm{mg}$ & 89 \\
9 & 4 & clomipramine & $75 \mathrm{mg}$ & 31 \\
10 & 1 & amitryptiline & $75 \mathrm{mg}$ & 28 \\
11 & 2 & viloxazine & $400 \mathrm{mg}$ & 56 \\
12 & 6 & amitryptiline & $225 \mathrm{mg}$ & 29 \\
13 & 2 & amitryptiline & $175 \mathrm{mg}$ & 46 \\
14 & 4 & amitryptiline & $175 \mathrm{mg}$ & 28 \\
15 & 5 & tranylcypromine & $20 \mathrm{mg}$ & 30 \\
\hline
\end{tabular}

consensus of two psychiatrists. Severity of depression was assessed by the 21-item Hamilton Rating Scale for Depression (21-HRSD) and the 17-item HRSD (Hamilton, 1960). The mean $( \pm S D) 21$ item HRSD score of the patients was $26.9 \pm 4.8$ (range 18-36) during depression and $5.3 \pm 3.5$ (range 1-10) after recovery. The mean ( \pm SD) 17-item HRSD score was $18.3 \pm 4.2$ (range 13-27) during depression and $3.5 \pm 2.7$ (range $1-9$ ) after recovery (Tables 1 and 2). Controls had no history of psychiatric disorder and were medication-free for at least 4 weeks.

For determination of GR binding characteristics and hormone data, $50 \mathrm{ml}$ blood was collected at 4 p.m. into prechilled plastic tubes containing EDTA. GR pharmacological characteristics were determined as described in detail elsewhere (Rupprecht et al., 1990).

A mononuclear cell fraction was prepared by sodium metrizoate-Ficoll density gradient centrifugation (Boyum, 1968). Cells were washed twice in phosphate-buffered saline (PBS) for $10 \mathrm{~min}$, incubated for $60 \mathrm{~min}$ at $37^{\circ} \mathrm{C}$ to allow sufficient dissociation of endogenous hormone, and then washed again. The final concentration of cells was determined using a Coulter counter (Model S5, Coulter Electronics Ltd, U.K.). Viability of cells exceeded 95\%, as judged from their ability to exclude trypan blue. Contamination by erythrocytes was less than $10 \%$, contamination by granulocytes and monocytes was less than $8 \%$. Binding experiments were carried out at $37^{\circ} \mathrm{C}$ in plastic microtiter plates in a total volume of 0.25 $\mathrm{ml}$. Non-specific binding was determined with unlabeled dexamethasone (final concentration 10 $\mu \mathrm{M})$ added immediately prior to the addition of $\left[{ }^{3} \mathrm{H}\right]$ dexamethasone (specific activity $84 \mathrm{Ci} / \mathrm{mmol}$ ). Saturation experiments were performed on each blood sample using increasing concentrations of $\left[{ }^{3} \mathrm{H}\right]$ dexamethasone from 1 to $40 \mathrm{nM}$. Saturation experiments were performed at equilibrium after a 90-min incubation period. After incubation bound ligand was separated from free ligand by rapid filtration through Scatron filters with a Titertek cell harvester (Scatron, U.K.) by washing with PBS ( $\mathrm{pH}$ 7.4) at room temperature. The filters were transferred into plastic vials, $5 \mathrm{ml}$ of a toluene-based scintillation cocktail was added and samples were monitored for tritium in a Beckman LS 1801 counter at about 54\% efficiency. All samples were assayed in triplicate with a variation within a single experiment of less than $7 \%$. The number of sites per cell and dissociation constants were estimated by computer-assisted Scatchard analysis. ACTH was measured by an immunoradiometric assay supplied by the Nichols Institute (San Juan Capistrano, CA, U.S.A.), which does not require extraction procedures (Raff and Findling, 1989). A soluble sandwich complex is formed by a ${ }^{125}$ I-labeled monoclonal antibody directed against N-terminal ACTH and a biotincoupled polyclonal antibody against $\mathrm{C}$-terminal ACTH. The sandwich complexes are bound by adding avidin-coated plastic bead. Unbound components are washed away and the radioactivity bound to the solid phase is monitored in a $\gamma$ counter. The lower detection limit was $1.5 \mathrm{pmol} / \mathrm{l}$, and the intra- and interassay coefficients of variation were $3 \%$ and $6.8 \%$, respectively. Values below the detection limit were recorded as $1.5 \mathrm{pmol} / 1$.

Cortisol was measured by a direct radioimmunoassay (Stalla et al., 1981). The lower detection limit was $25 \mathrm{nmol} / 1$, and the intra- and interassay coefficients of variation were $5 \%$ and $9 \%$, respectively.

As receptor and hormone data were normally distributed, differences between patients and con- 
TABLE 3

MEAN $\pm S D$ GR SITES PER CELL AND $K_{d}$ VALUES OF PATIENTS DURING DEPRESSION $(n=15)$ AND AFTER RECOVERY $(n=15)$, AND OF HEALTHY CONTROLS $(n=15)$

\begin{tabular}{lll}
\hline & $\begin{array}{l}\text { GR sites per cell } \\
(\text { mean } \pm \text { SD) }\end{array}$ & $\begin{array}{l}K_{\mathrm{d}}(\mathrm{nM}) \\
(\text { mean } \pm \mathrm{SD})\end{array}$ \\
\hline Depressed & $3297 \pm 1154$ & $15.3 \pm 3.9$ \\
Recovered & $3287 \pm 1302$ & $11.9 \pm 5.8$ \\
Controls & $3421 \pm 838$ & $13.3 \pm 5.6$ \\
\hline
\end{tabular}

trols were analyzed using one-way analysis of variance (ANOVA) followed by post hoc comparisons with Student's $t$-test. Comparisons between depressed and recovered subjects were made by the $t$-test for paired samples. Correlation data were obtained by Pearson's product moment correlation. All significance levels are two-tailed.

\section{Results}

The number of GR sites per cell and the dissociation constants are given in Table 3 for the depressed and recovered subject and for the healthy controls. Neither GR number nor affinity showed any difference between the groups studied. There was no relationship between the length of the medication-free interval, the duration of the current episode, the duration of treatment, the type of antidepressant, the number of previous depressive episodes, age, body weight, severity of depression and glucocorticoid receptor number or affinity. 4 p.m. ACTH or cortisol concentrations did not differ between the groups studied (Table 4) and were not related significantly to any of the clinical variables.

\section{TABLE 4}

Mean \pm SD ACTH and cortisol levels of patients during depression $(n=15)$ and after recovery $(n=15)$, and of healthy controls $(n=15)$

\begin{tabular}{lll}
\hline & $\begin{array}{l}\text { ACTH }(\mathrm{pmol} / \mathrm{l}) \\
(\text { mean } \pm \mathrm{SD})\end{array}$ & $\begin{array}{l}\text { Cortisol }(\mathrm{nmol} / \mathrm{l}) \\
(\mathrm{mean} \pm \mathrm{SD})\end{array}$ \\
\hline Depressed & $4.0 \pm 1.4$ & $257.1 \pm 120.3$ \\
Recovered & $4.6 \pm 1.9$ & $194.3 \pm 77.9$ \\
Coutrols & $3.6 \pm 1.2$ & $218.0 \pm 77.5$ \\
\hline
\end{tabular}

\section{Discussion}

Our study of GR binding characteristics did nol reveal any difference between depressed, recovered, and control subjects. These findings confirm previous investigations (Schlechte and Sherman, 1985) and suggest that the glucocorticoid receptor is not down-regulated by hypercortisolemia in depression. However, others have reported lower glucocorticoid binding sites in depression (Gormley et al., 1985; Whalley et al., 1986). We did not find a significant elevation of 4 p.m. baseline cortisol during the depressive episode, however, this does not exclude hypercortisolemia in our study, since it was only a single point measurement and the HPA axis is relatively quiescent at this time (Amsterdam et al., 1987). However, the depressed patients showed an attenuated suppression of ACTH by dexamethasone even after metyrapone pretreatment (Rupprecht et al., 1991) which points to a derangement of the feedback mechanism of the HPA system in the majority of these subjects.

Only one study has examined glucocorticoid binding in patients recovered from major depression (Hunter et al., 1988) and found normal values when compared with controls, which is in accordance with our results. However, this investigation did not compare the recovered with the depressed state. We could not detect any differences in baseline GR binding between depressed and recovered subjects. However, a decreased plasticity of GR regulation (e.g., up- and down-regulation) following major shifts of endogenous hormone values in the face of unchanged baseline GR numbers has recently been noted in depressed patients (Rupprecht et al., 1991). These data indicate a deficiency in GR autoregulation rather than a change in absolute receptor number during depression, which cannot be detected by baseline measurements but only in regulation studies.

We could not establish a relationship between antidepressant medication and GR binding. This is in accordance with the results of Hunter et al. (1988) but contrasts with the report of Whalley et al. (1986), who noted higher GR sites in depressed patients pretreated with antidepressants. However, the glucocorticoid receptor is regulated in a more differentiated manner in the hippocampus, where 
it responds to even slight changes in endogenous hormone levels, than in peripheral tissues (McEwen et al., 1987). Of particular interest in this context are recent observations that antidepressants might cause an increase in GR immunoreactivity in the locus coeruleus of rats (Kitayama et al., 1988) and an increase in GR mRNA in primary neuronal cultures (Pepin et al., 1989). To determine the validity of these findings and whether the increase in GR density might be one mechanism of action of antidepressant drugs should be a matter of future studies in molecular neuroendocrinology.

\section{References}

American Psychiatric Association (1987) Diagnostic and Statistical Manual of Mental Disorders, 3rd edn, revised. American Psychiatric Association, Washington, DC.

Amsterdam, J.D., Maislin, G., Winokur, A., Kling, M. and Gold, P. (1987) Pituitary and adrenocortical reponses to the ovine corticotropin-releasing hormone in depressed patients and healthy volunteers. Arch. Gen. Psychiatry 44, 775-781.

Boyum, A. (1968) Separation of leukocytes from blood and bone marrow. Scand. J. Clin. Lab. Invest. 21, 97-107.

Carroll, B.J., Martin, F.I. and Davis, B.M. (1968) Resistance to suppression by dexamethasone of plasma 11-OHCS levels in severe depressive illness. Br. Med. J. 3, 285-287.

Fang, V.S., Tricou, B.J., Robertson, A. and Meltzer, H.Y. (1981) Plasma ACTH and cortisol levels in depressed patients: relation to the dexamethasone suppression test. Life Sci. 29, 931-938.

Gormley, G.J., Lowy, M.T., Reder, A.T., Hospelhorn, V.G., Antel, J.P. and Meltzer, H.Y. (1985) Glucocorticoid receptors in depression: relationship to the dexamethasone suppression test. Am. J. Psychiatry 142, 1278-1284.

Hamilton, M. (1960) A rating scale for depression. J. Neurol. Neurosurg. Psychiatry 23, 56-62.

Hunter, R., Dick, H., Christie, J.E., Goodwin, G.M. and Fink, G. (1988) Lymphocyte glucocorticoid receptor binding in depression: normal values following recovery. J. Affect. Disord. 14, 155-159.

Kitayama, I., Janson, A.M., Cintra, A., Fuxe, K., Agnati, L.F., Ögren, S.O., Härfstrand, A., Eneroth, P. and Gustafsson, J.A. (1988) Effects of chronic imipramine treatment on glucocorticoid receptor immunoreactivity in various regions of the rat brain. J. Neural Transm. 73, 191-203.

Linkowski, P., Mendlewicz, J., Leclercq, R., Brasseur, M., Hubain, P., Goldstein, J., Copinschi, G. and van Cauter E. (1985) The 24-hour profile of adrenocorticotropin and cortisol in major depressive illness. J. Clin. Endocrinol. Metab. 61, 429-438.

Linkowski, P., Mendlewicz, J., Kerkhofs, M., Leclercq, R., Goldstein, J., Brasseur, M., Copinschi, G. and van Cauter, E. (1987) 24-Hour profiles of adrenocorticotropin, cortisol, and growth hormone in major depressive illness: effect of antidepressant treatment. J. Clin. Endocrinol. Metab. 65, 141-152.

Lowy, M.T., Reder, A.T., Gormley, G.J. and Meltzer, H.Y. (1988) Comparison of in vivo and in vitro glucocorticoid sensitivity in depression: relationship to the dexamethasone suppression test. Biol. Psychiatry 24, 619-630.

Matthews, J., Akil, H., Greden, J., Charney, D., Weinberg, V., Rosenbaum, A. and Watson, S.J. (1986) $\beta$-Endorphin $/ \beta$ lipotropin immunoreactivity in endogenous depression. Arch. Gen. Psychiatry 43, 374-381.

McEwen, B., Chao, H., Spencer, R., Brinton, R., Macisaac, L. and Harrelson, A. (1987) Corticosteroid receptors in brain: relationship of receptors to effects in stress and aging. Ann. NY Acad. Sci. 512, 394-401.

Meltzer, K.Y., Fang, V.S., Tricou, B.J., Robertson, A. and Piyaka, S.K. (1982) Effect of dexamethasone on plasma prolactin and cortisol levels in psychiatric patients. Am. J. Psychiatry 139, 763-769.

Pepin, M.C., Beaulieu, S. and Barden. N. (1989) Antidepressants regulate glucocorticoid receptor messenger RNA concentrations in primary neuronal cultures. Mol. Brain Res. 6, 77-83.

Raff, H. and Findling, J.W. (1989) A new immunoradiometric assay for corticotropin evaluated in normal subjects and in patients with Cushing's syndrome. Clin. Chem. 35, 596-600.

Rupprecht, R., Barocka, A., Jecht, E., Noder, M., Pichl, J. and Schwarz, W. (1987) Prolactin response to dexamethasone: a study on normal controls and depressed patients. Acta Psychiatr. Scand. 76, 139-143.

Rupprecht, R., Barocka, A., Beck, G., Schrell, U. and Pichl, J. (1988) Pre- and postdexamethasone plasma ACTH and $\beta$-endorphin levels in endogenous and non-endogenous depression. Biol. Psychiatry 23, 531-535.

Rupprecht, R., Rupprecht, C., Rupprecht, M., Noder, M. and Mahlstedt, J. (1989) Triiodothyronine, thyroxine and TSH response to dexamethasone in depressed patients and normal controls. Biol. Psychiatry 25, 22-32.

Rupprecht, R., Kornhuber, J., Wodar7, N., Göbel, C., Lugauer, J., Sinzger, C., Beckmann, H., Riederer, P. and Müller, O.A. (1990) Characterization of glucocorticoid binding capacity in human mononuclear leukocytes: increase by metyrapone is prevented by dexamethasone pretreatment. J. Neuroendocrinol, 2, 803-806.

Rupprecht, R., Kornhuber, J., Wodarz, N., Lugauer, J., Göbel, C., Haack, D., Müller, O.A., Riederer, P. and Beckmann, H. (1991) Disturbed glucocorticoid receptor autoregulation and corticotropin response to dexamethasone in depressives pretreated with metyrapone. Biol. Psychiatry (in press).

Schlechte, J.A. and Sherman, B. (1985) Lymphocyte glucocorticoid receptor binding in depressed patients with hypercortisolemia. Psychoneuroendocrinology 10, 469-474.

Stalla, G.K., Giesemann, G., Müller, O.A., Wood, W.G. and Scriba, P.C. (1981) The development of a direct homologous radioimmunoassay for serum cortisol. J. Clin. Chem Clin. Biochem. 19, 427-434.

Whalley, L.J., Borthwick, N., Copolov, D., Dick, H., Christie, J.E. and Fink, G. (1986) Glucocorticoid receptors and depression. Br. Med. J. 292, 859-861. 